\title{
KNOWING TO PRESERVE: THE BUILDING COGNITION PROCESS FOR THE CONSERVATION OF ST'ANNE CHARTERHOUSE, COVENTRY - UK
}

\author{
RAFAELA SIMONATO CITRON \\ Department of Architecture and Urbanism, IMED, Brazil
}

\begin{abstract}
Every architectural project involving building heritage, for either its conservation or its adaptive reuse, requires an intensive phase of research and analysis in order to learn about the building on which one will intervene. A project done without this knowledge will surely lead to a series of bad decisions that could cause irreparable damage to the building. This article presents as case study the St Anne Charterhouse, a Carthusian Monastery in the city of Coventry, England, and aims to show the cognition process conducted between the months of January and February 2013. It will demonstrate how the historical research, architectural survey and stratigraphic analysis were conducted on the building, showing step by step the knowledge acquired and how each piece of information has contributed to the reconstruction of the Priory during the Middle Ages and to arriving to a proposal for its adaptive reuse, opening The Charterhouse to the residents of Coventry. Knowing where every building was located within the monastery complex was important because only one building still stands after the rest was demolished with the dissolution of the monasteries in 1540 and to ensure that no possible use would conflict with the history of the monument. The building has gone through a long process of cognition that revealed some data that changed some of the initial design ideas. The results showed, for example, that instead of a building with four rooms as we previously thought, there were actually two buildings with no physical connection between them and that an important medieval painting had not been painted over but vanished with the replacement of the original wall. This research has been critical to the assessment of the possibilities for the reuse of The Charterhouse and will be exposed inside the building so the community can learn about its history.
\end{abstract}

Keywords: Charterhouse, cognition process, monastery.

\section{INTRODUCTION}

It is known that it is not possible to do any proposal for a heritage building without first getting to know the building [1]. To be able to work on a proposal for the conservation and reuse of The Charterhouse, it was essential to first understand the building and the site history. The medieval building standing today on site was part of a Carthusian priory and it is the only remaining building on site. This article is part of the knowledge process that included, in a first phase, a research on other monasteries of the same religious order in the UK to find out how the monks lived inside the priory and what were its architectural features. After that, the research went more specific, with a historical research and mapping of the remaining building of The Charterhouse, until we got to the analysis phase through the architectural survey and stratigraphic analysis of the standing building.

The goal of this cognition process was to understand how the monastic complex was configured in the medieval period and in particular the changes that the existing building has suffered over the years. The remaining three-floored building, built in stone masonry, used to contain the Prior's house and the refectory, but today there is nothing that indicates that it was a Carthusian Priory, except for its name, Charterhouse, which comes from Chartreuse, the name of the mountain where the first Carthusian monastery has been installed, in France. The church was also demolished along with other buildings within the complex. 
The following sections show step by step the knowledge acquired during the process and how each one has contributed to the reconstruction of the monastery during the Middle Ages and to arriving to a proposal for its adaptive reuse.

\section{THE CHARTERHOUSE}

\subsection{Location and history}

The Priory of St Anne, or The Charterhouse, is located in Coventry, England. Coventry is a metropolitan city in the province of West Midlands in England and is located $153 \mathrm{~km}$ north west of central London and $31 \mathrm{~km}$ east-south of Birmingham. Coventry was one of the most important cities in England during the Middle Ages thanks to its textile production booming. The Charterhouse is located next to the river Sherbourne, a few minutes' walk, along London Road, of the ancient walls of the medieval city (Fig. 1).

The Charterhouse was originally part of the Priory of St Anne, founded in 1381. After the dissolution of the monasteries in 1539, most of the buildings were demolished, leaving only a stone building still standing (two wings have been further demolished in 1848) [2]. The building is Grade I listed and the surrounding grounds have the status of Scheduled Ancient Monument. The buildings classified as Grade I in England are of exceptional interest, sometimes considered of international importance.

The monks who lived there were of the Carthusian order. Every monk lived alone in a cell, which consisted of only two or three small rooms, and there they would remain silent and alone, dressed in the most minimal clothing, eating the most meagre diet (peas and fish typically), and they would only meet with other brothers in the choir or for prayer in the chapterhouse [3].

The dissolution of the monasteries in the 16th century by King Henry VIII, after the breakaway with Rome, caused a devastating effect in Coventry. As a method of reducing the enormous power that the Church had all around the world, Henry began to slowly dissolve the secular institutions. The first monasteries in Coventry to fall were The Whitefriars and The Greyfriars and then The Charterhouse [4].

After that, the building was converted into private residence and is now owned by The Charterhouse Preservation Trust.
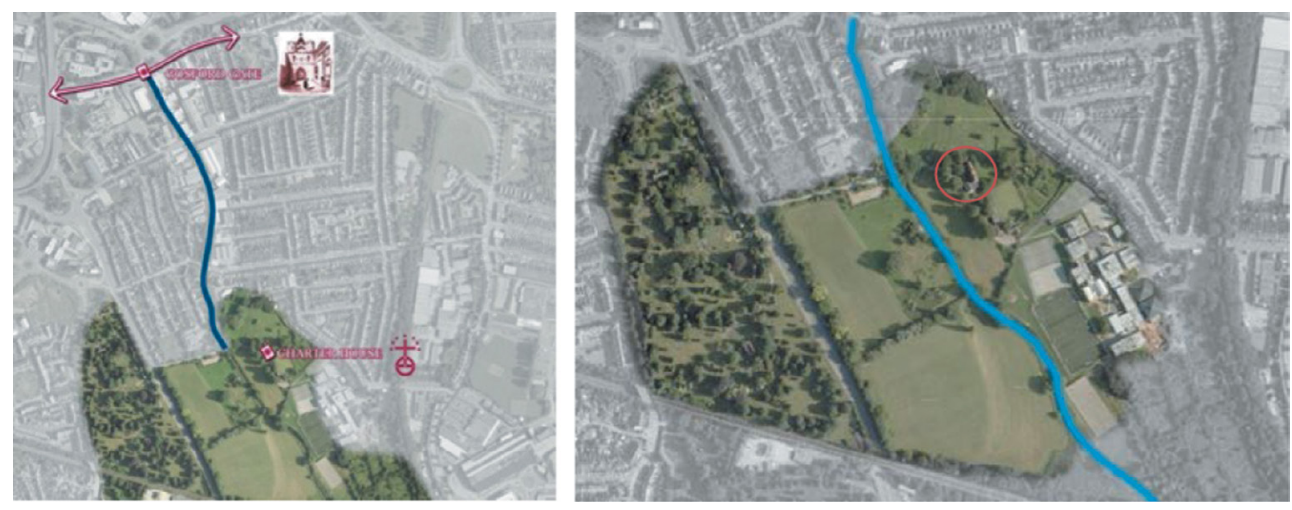

Figure 1: Location of The Charterhouse. 


\subsection{The building}

The remaining building is believed to be the Prior's accommodation, built in sandstone from the 15th century. A short extension on the left, which was added in the 16th century when the property became a private home, after the dissolution of the monasteries, is built with stone walls on the ground floor and timber framed above (Figs. 2 and 3).

Some original features can be found in the building, including a stone fireplace, some original stone shelves and carved wooden beams. There is also ancient oak panelling, possibly from the 17th century, and doors and sash windows from the 18th century. Perhaps the most notable features are medieval wall paintings from the 16th and 17th centuries, depicting the crucifixion and important elements of the English Renaissance (Figs. 4 and 5).

Besides the Prior's House, part of the north wall of the church and most of the perimeter walls still remain. With the exception of some repair works in grey stone, all the surviving walls are in red sandstone from Coventry.

Like all British convent buildings converted into private residences, the survivor building, located on the northwest side of the monastic cloister, has gone through some important

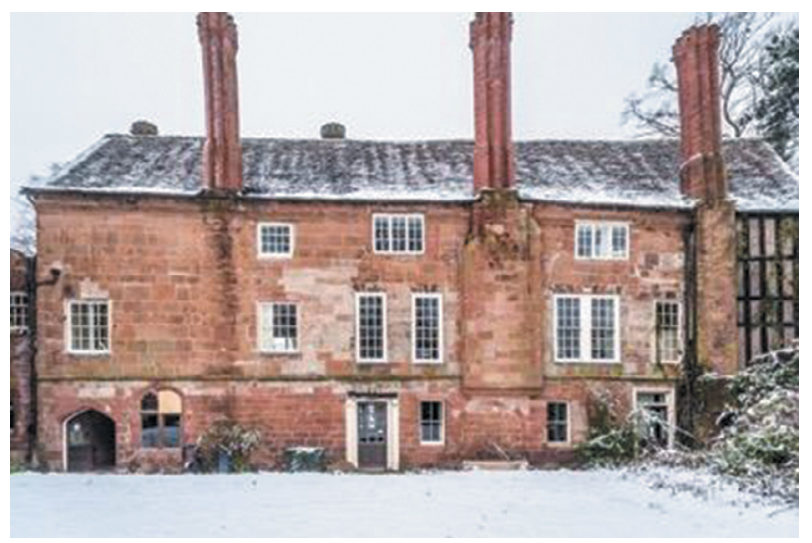

Figure 2: The Charterhouse, east façade.

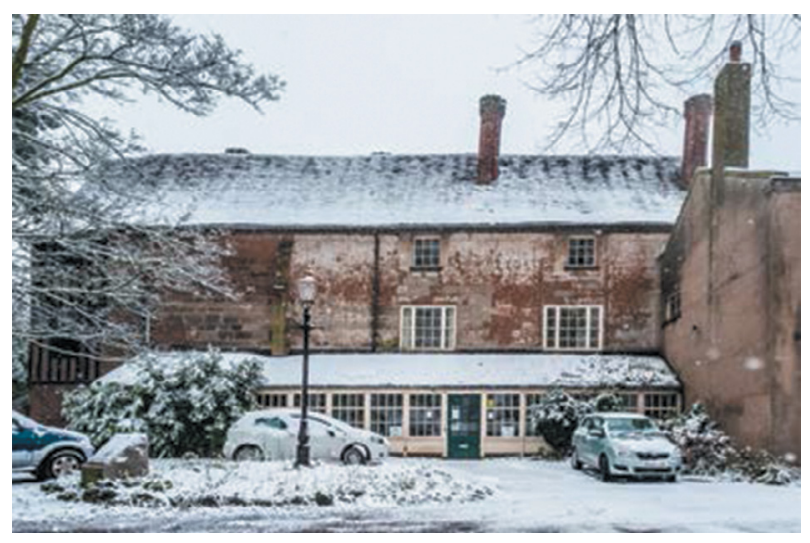

Figure 3: The Charterhouse, west façade. 


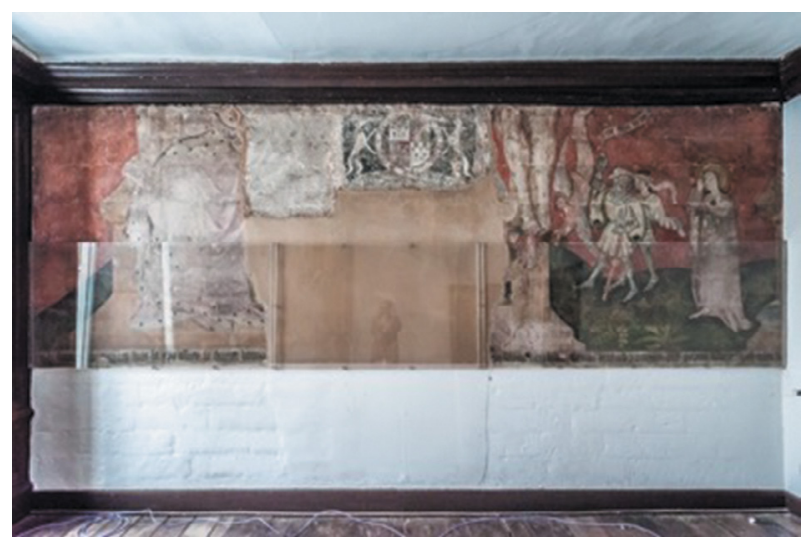

Figure 4: The medieval painting.

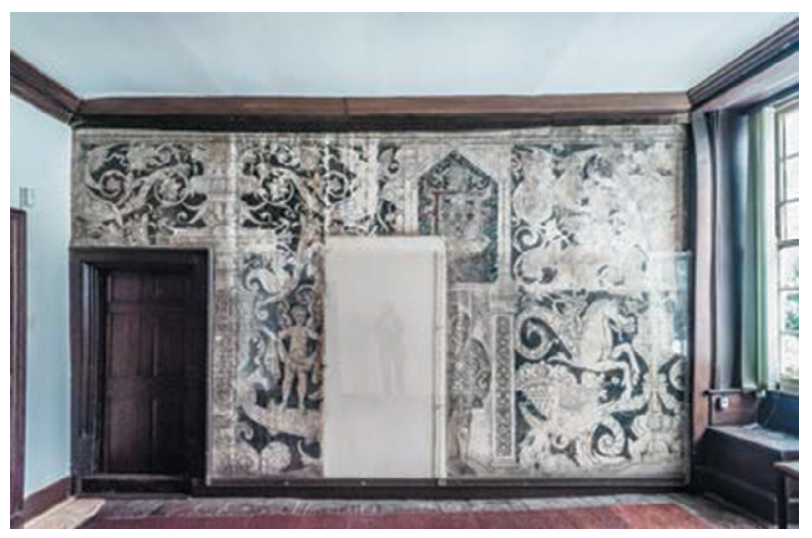

Figure 5: The English Renaissance painting.

changes over the years. The building, originally of two floors, has received a third floor, new roof and a northern extension after the dissolution. The first changes are believed to be from the mid-16th century and the last ones from the 1960s. In the initial phase, the interiors have been modified by the insertion of partition walls, forming hallways that now run from north through south of the building, both in the first and second floors.

\section{THE COGNITION PROCESS}

This knowledge process was possible by analysing the building and grounds through indirect and direct sources. The first part, the research on indirect sources, will not be covered in this article. As indirect sources we are considering the historical research on other Carthusian Monasteries and the cartographic research. The data collected made it possible to assume the location of the main buildings within the complex, along with the records of the excavations conducted in The Charterhouse in 1968-87, by Ian Soden [5].

Once all the information was collected, it was possible to continue with the research on the direct sources, which consisted of the reading of the building itself, via architectural survey and stratigraphic analysis of the building. 


\subsection{The architectural survey and photo elevations}

The survey represents the preliminary activity of each project of conservation, and in the case of The Charterhouse it was done just after the first site inspection. This phase seeks to understand all aspects of the building, leaving behind the old belief that this stage is a simple measurement operation, assimilating it rather to a real reading of the building.

The information that we had prior to the survey was that the medieval painting of the crucifixion had been divided into two by the insertion of the second floor in the 16th century and the top part of the painting had been removed or covered, although no traces of the painting in the second floor have ever been found. The survey showed that it would never have been possible to find the top of the painting because the ancient masonry was destroyed and a new wall was built almost in the same place, which has caused the confusion (Figs. 6 and 7).

For the survey of the elevations, the use of photographs was crucial and gave the supporting documentation for the stratigraphic analysis, which will be shown next. Due to the difficulty of direct measurement, the elevations were produced with the photographic images, using the

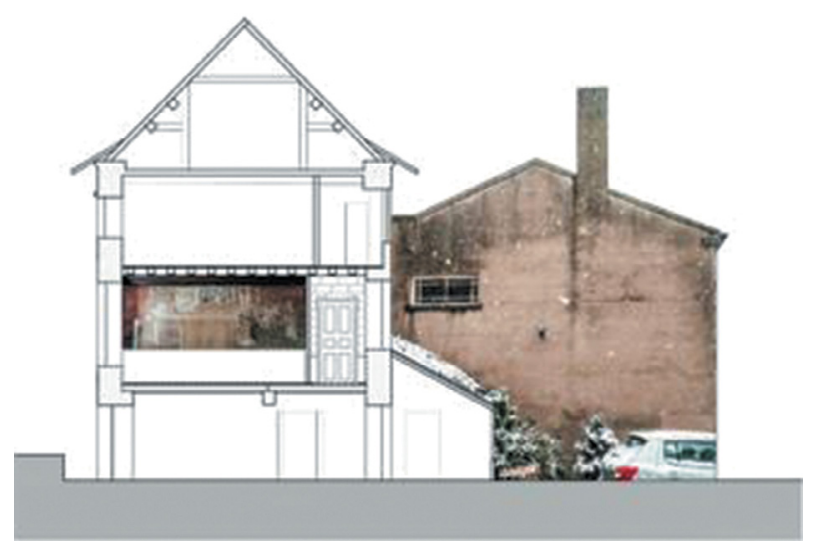

Figure 6: Section showing painting in the first floor.

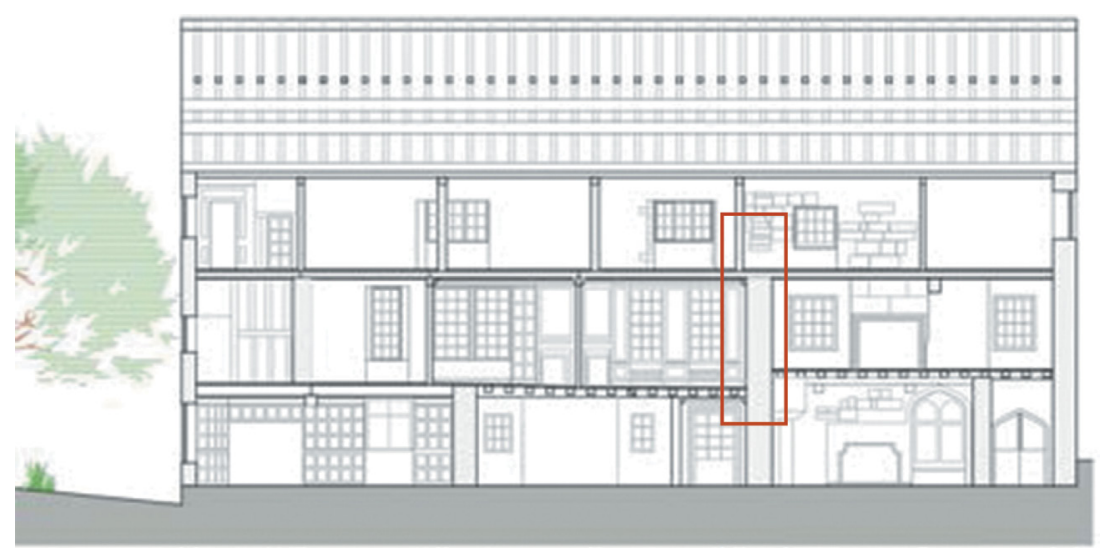

Figure 7: Section showing that top part was demolished. 


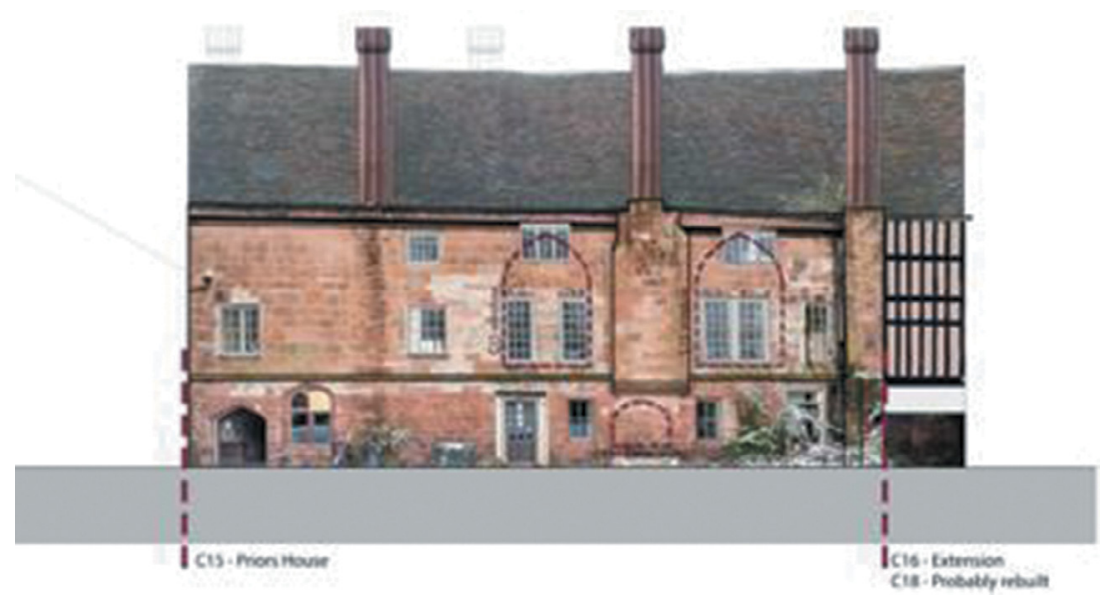

Figure 8: Photo elevation and analysis of East elevation.

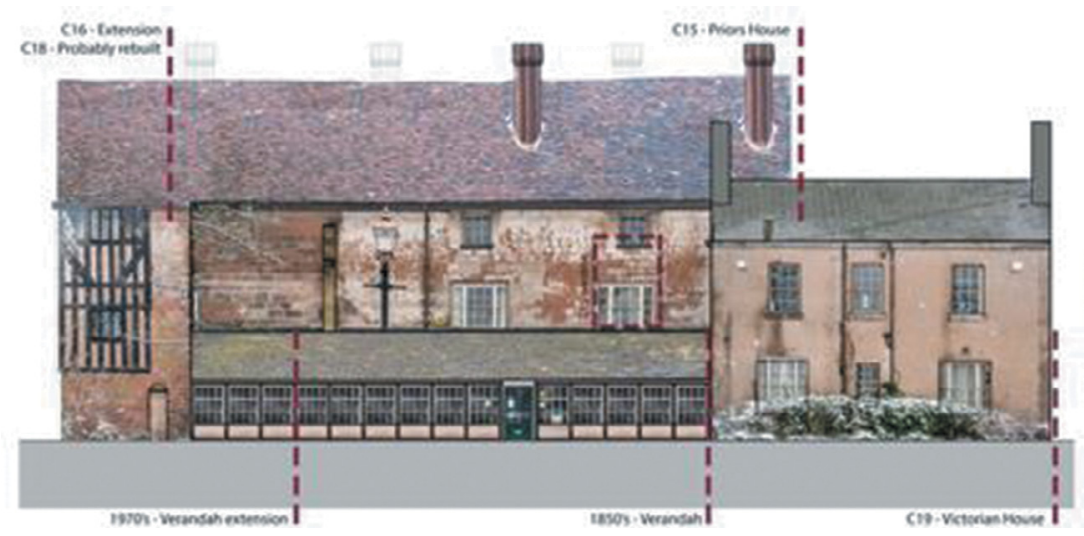

Figure 9: Photo elevation and analysis of West elevation.

image rectification method, a technique that allows you to reduce the geometric distortions to get correct dimensional information (Figs. 8 and 9).

With the architectural survey, it has been possible to recognize some of the changes that the building has gone through. Besides the demolition of an important wall paining, as mentioned previously, it became clear, while drawing the elevations, that two big medieval windows on the east façade have been closed off, probably after the dissolution, when the building became a private house.

\subsection{The stratigraphic survey}

Along with information gathered with historical research and geometric survey, the stratigraphic analysis made it possible to read the signs presented in the building. This method was first used in the 1980s, when architecture archaeology begun to be studied. Architectural archaeology applies the methods of archaeological research in a non-destructive way. With this method the history of the building can be reconstructed by analysing its construction techniques [6]. 
In the architectural context, the stratigraphic reading is based on the observation of the external surface by observing all layers simultaneously. The building then becomes a direct source of information. In the case of The Charterhouse, the reading was easy due to the absence of plaster that would hide the brickwork. At the same time, the fact that the stone used is local and has been used in different stages of the building history made the reading a little more complicated. Being a non-destructive technique, the stratigraphic analysis is based only on what is visible.

The identification of the stratigraphic units (SUs) was the first thing done and has been based on the photo elevations. The SUs are homogenous areas with the exact same constructive technique and they can be positive SUs, those that have a continuity clearly distinguishable or negative SUs, those due to removal of material.

To recognize the different SUs, it has been taken in consideration the type of materials used in the facades.Three different types of stone have been identified, one grey and two red, one more regular than the other, and these three types of masonry were encountered all over the observed façade (east). Doors and windows have also been identified, along with the roof and architectural elements, such as the chimneys. The SUs recognized on site were then marked and numbers in the photo elevation. The masonry SUs are numbered from 1001 to 1018, the architectural elements from 2001 to 2004 and the openings from 3001 to 3013 (Fig. 10).

The numbering of the SU does not necessarily match with the stratigraphic sequence. The SUs were then related based on the following: an SU binds to another: in the case of clamped walls, indicating contemporaneity; an SU fills another: it means an existing opening has been closed off and indicates posteriority; an SU cuts another: it means a transaction of demolition and indicates a posteriority; an SU leans to the other: in the case in which a masonry leans to a pre-existing, which indicates posteriority [7].

Five phases have been identified: the first and second were two different phases of construction; however, more or less from the same historical period and could be identified by two different types of stone. The third refers to infills made after the dissolution of the monastery, when the building became a private home. The fourth phase is the openings, with the typical windows from the Georgian period in England, from the 18th century. Finally, the fifth phase corresponds to the replacement of the roofs and chimneys (Fig. 11).

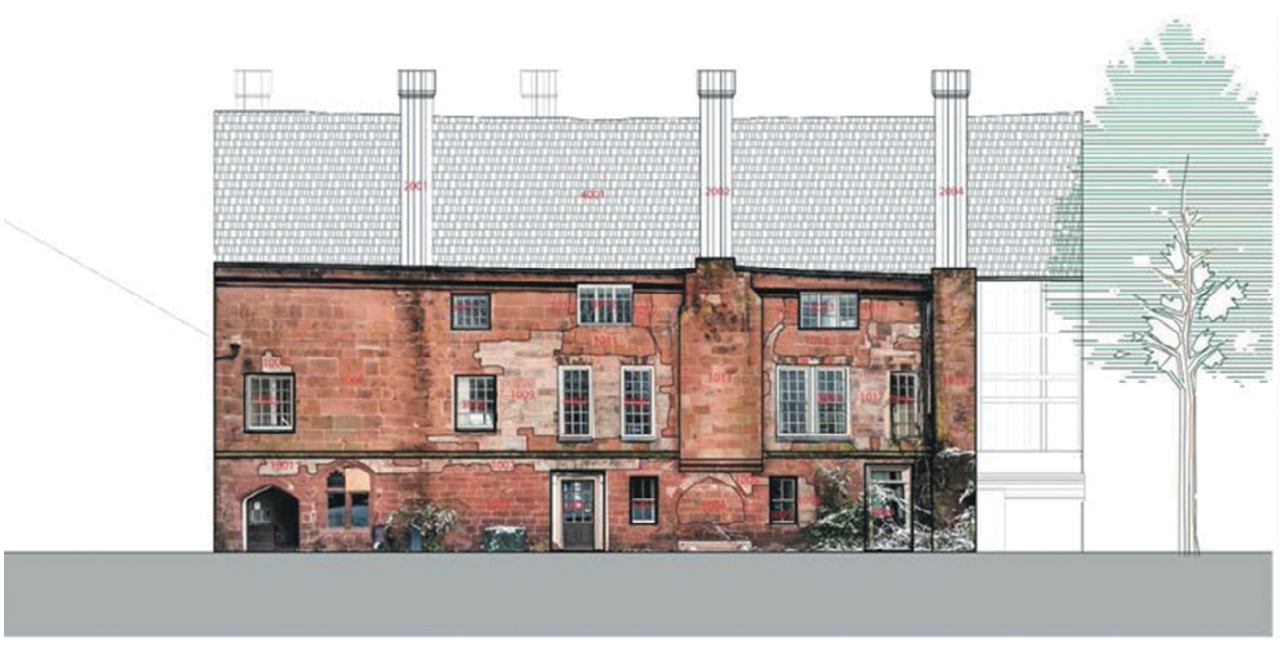

Figure 10: Stratigraphic analysis. 


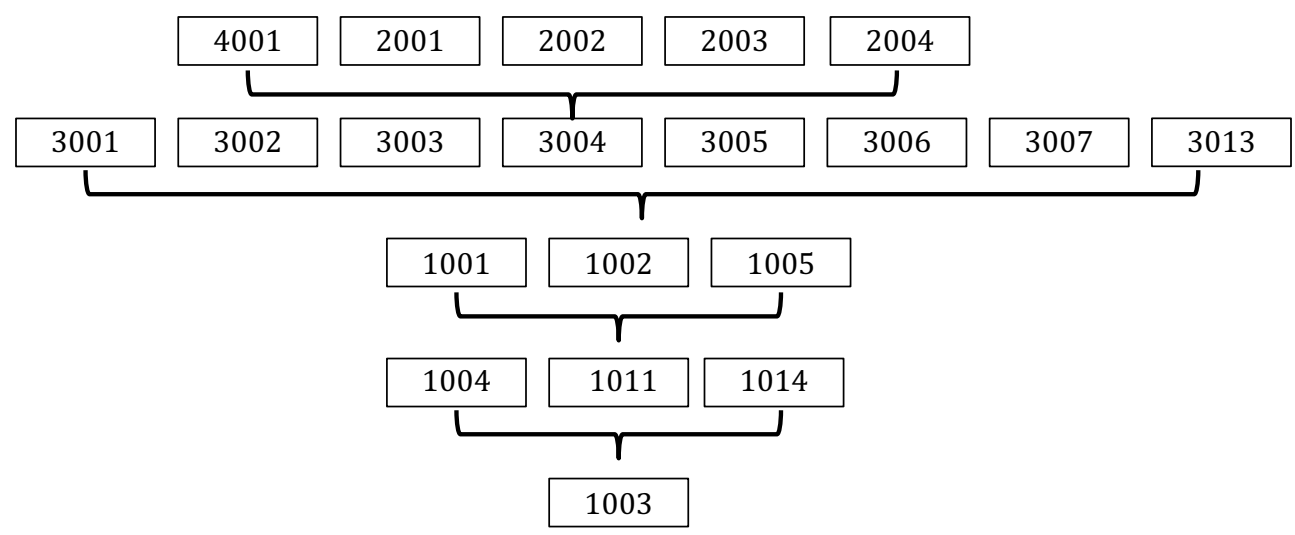

Figure 11: Stratigraphic units.

The data obtained with the stratigraphic analysis of the elevations gave the answers needed to understand what happened to the building, which became the basis for any proposal solutions for its future use. The interiors were also analysed and the modifications could also be identified and will be shown next.

\subsection{Chronological dating}

After the stage of collection and registration of data from the direct observation of the building, it was possible to move to the interpretive phase. The details were worked out together with the data acquired with the analysis on indirect sources (historical research, mapping, etc.). The dating based on the building stratigraphy is not absolute and needs to be combined with other dating techniques [8]. For this purpose, the stratigraphy was enough and produced a stable framework to work on.

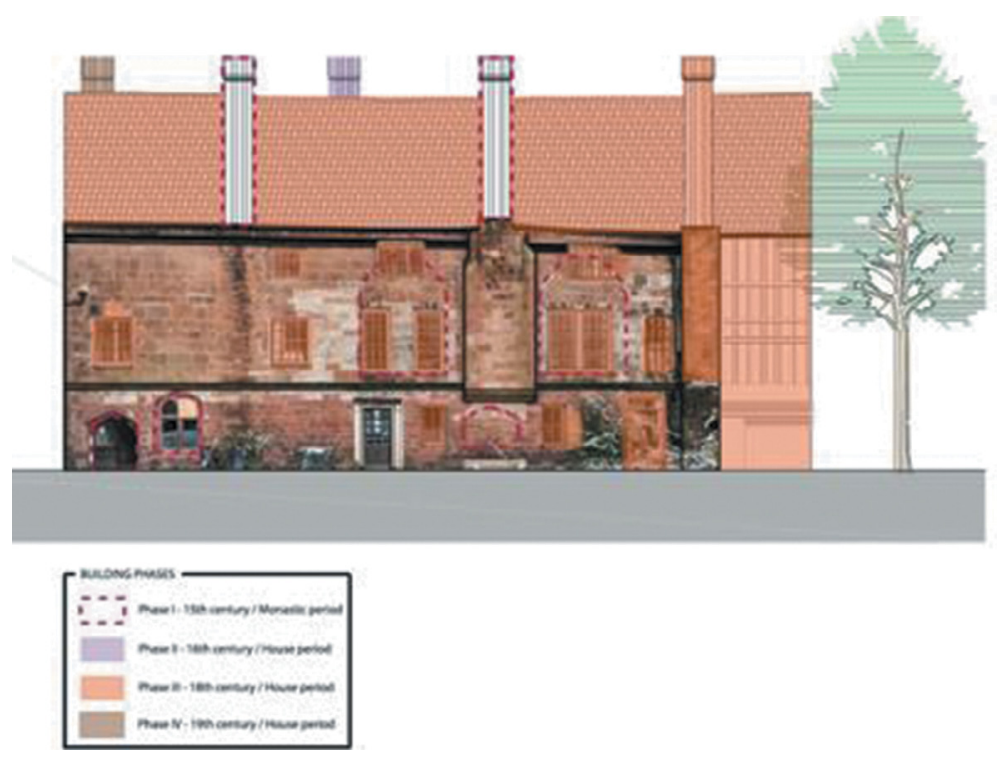

Figure 12: Chronology, east elevation. 


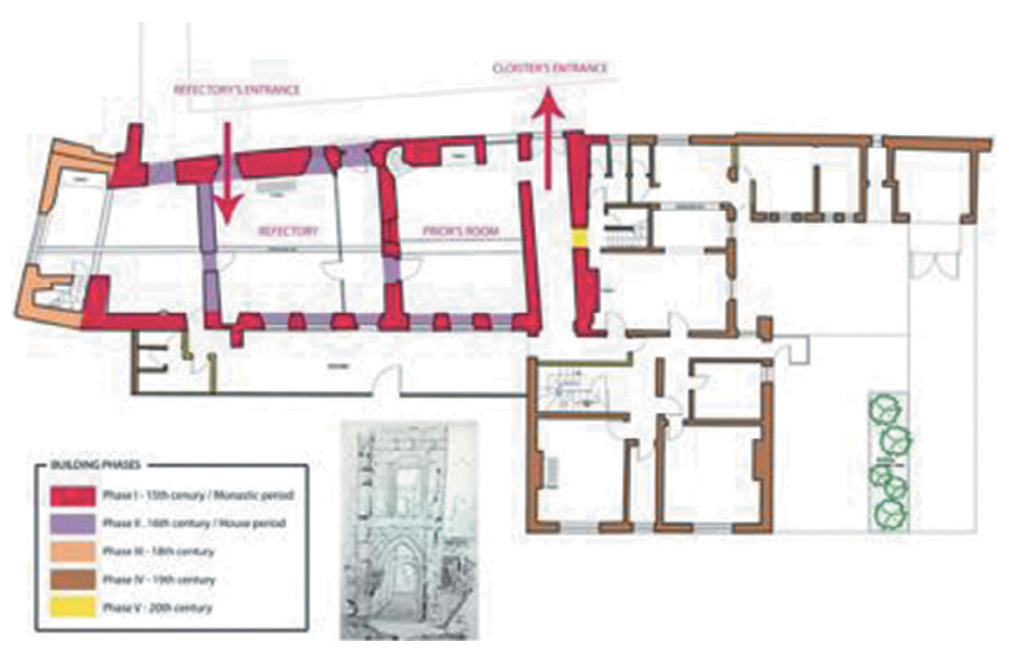

Figure 13: Chronology, ground floor.

With all units arranged, a chronological sequence has been assigned and the units have become the evolutionary stages of the building modifications. Each of these stages, and supported by an adequate investigation of indirect sources, refers to a specific historical period (Figs. 12 and 13).

- Phase I - 15th century, monastic period

- Phase II - 16th century, house period

- Phase III - 18th century, house period

- Phase IV - 19th century, house period

- Phase V - 20th century, house period.

The result of this will help tell the history of the building and will be the base for the adaptive reuse, which intends to respect the phases of the building.

\section{RESULTS}

\subsection{The reconstruction of the medieval monastery}

To the community of Coventry, The Charterhouse of St'Anne has always been a mystery. Even if they have always used the surrounding grounds as their park, only in 2012, in an 'open day', they were invited to enter the building and learn a bit about the history of the monastery.

To help tell this story, the medieval monastery was reconstructed in a three-dimensional model, based on the research (Fig. 14). From the archaeological excavations, we knew with certainty the location of the church and the monks' cells and these, together with the standing building, were the starting point for the three-dimensional model. Although only five cells have been excavated, it is known from historical research (the research on indirect sources, which have not been covered in this article) that there were in total eleven, six to the east of the cloister, four to the south and two to the west of the cloister. 


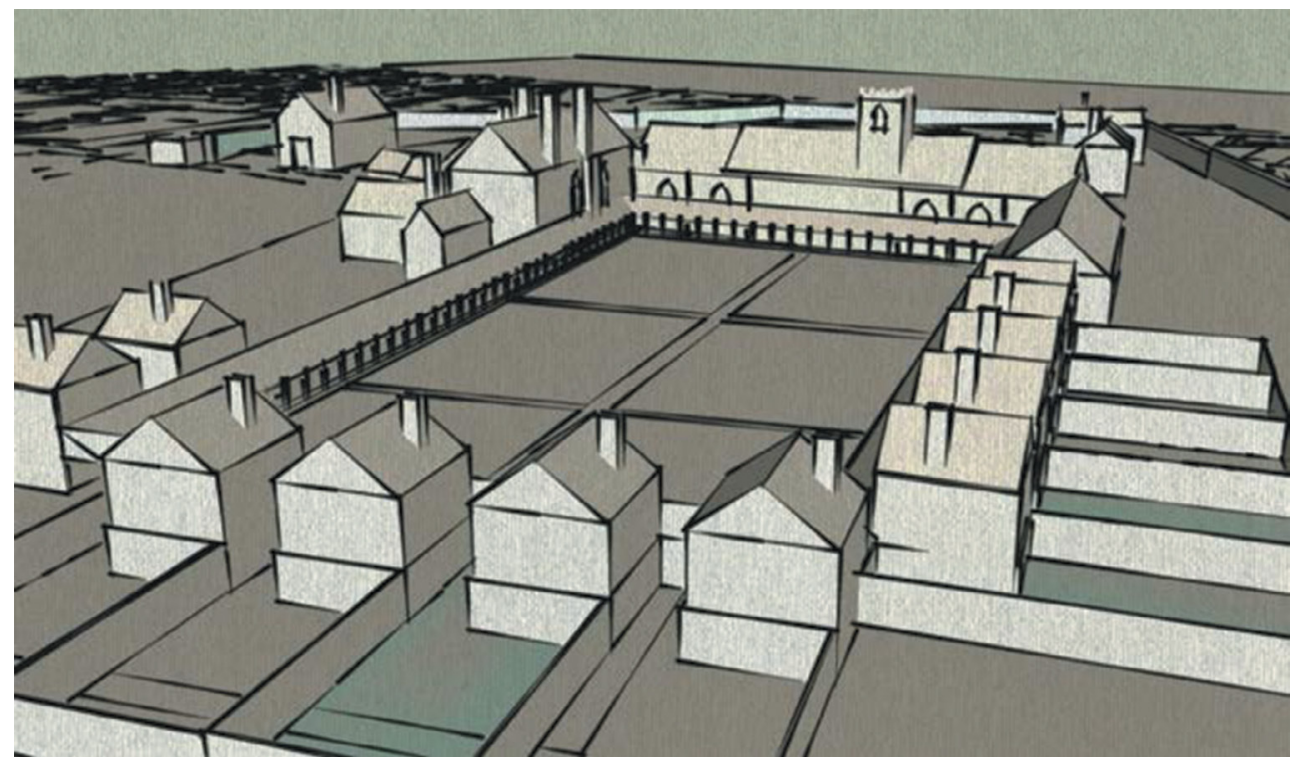

Figure 14: Three-dimensional reconstruction of The Charterhouse.

No excavation has been done in the supposed location of the chapterhouse, but it is known, from the research on other monasteries throughout Europe, this would usually be by the east side of the cloister. To the north of the church, the excavations found part of what is believed to be the cloister of the lay brothers, who certainly were outside the cloister of monks.

To the west of the survival building, based on the usual configuration of the Carthusian Monasteries and also on drawings made in the 19th century, were located the service homes, the kitchen, the bakery, etc. Near the bridge of access to the monastery, there was probably the home of the prosecutor.

The Prior's house (the surviving building) was analysed separately with bases in historical research but mainly by reading the building through the stratigraphic analysis. It has always been said that originally it was a two-floored house which contained the accommodation of the prior, the refectory and the guest house. The southern part of the house was certainly composed of two floors in the monastic period, and we know this by the presence of a beautiful stone staircase connecting the ground floor and the first, which can be seen now only in the ground floor. The whole southern part of the building contained the housing of the prior on the ground floor, which was probably very similar to that of other monks and the first floor was divided into two private rooms for the use of the prior, such as study and pray. A second floor was added later.

The north side of the building has always been thought of as the refectory on the ground floor due to the presence of lavatory in the east facade, where monks used to wash their hands before eating and entering the church, and the guest house on the first floor. However, the medieval painting of the crucifixion, today on the first floor, would most certainly be in the refectory, rather than in the guest house, as most Carthusian Monasteries had a crucifixion painting in the refectory. Besides, there are no traces of a staircase connecting the ground floor to the first, the only staircase is the one in the Prior's house, which had no internal connection with the refectory (there is currently a connection through an opening that cuts the 


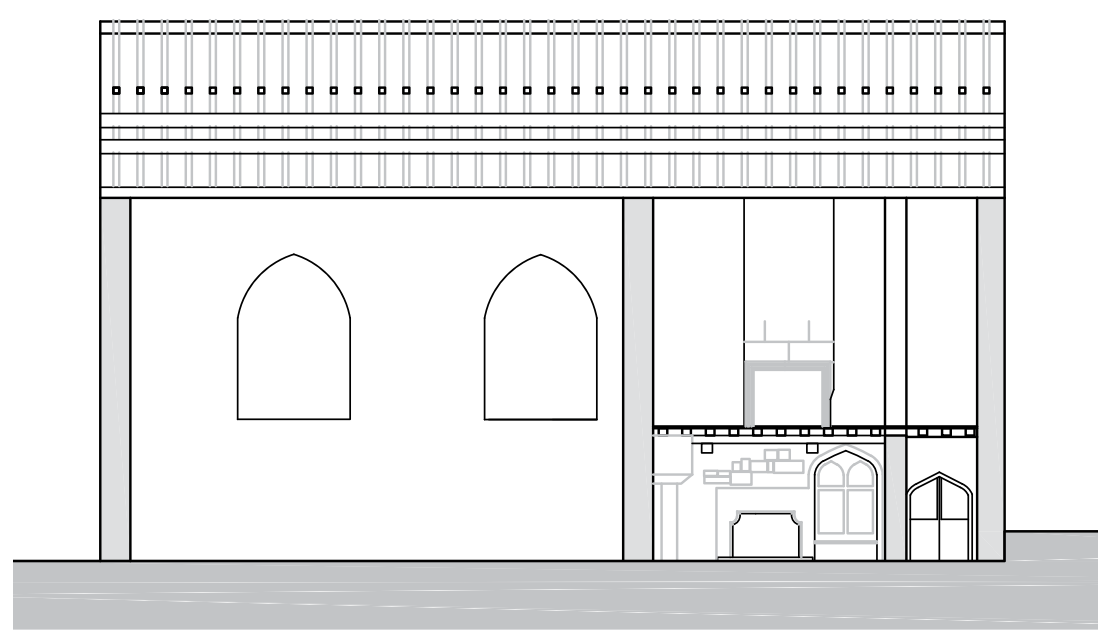

Figure 15: Assumed original longitudinal section.

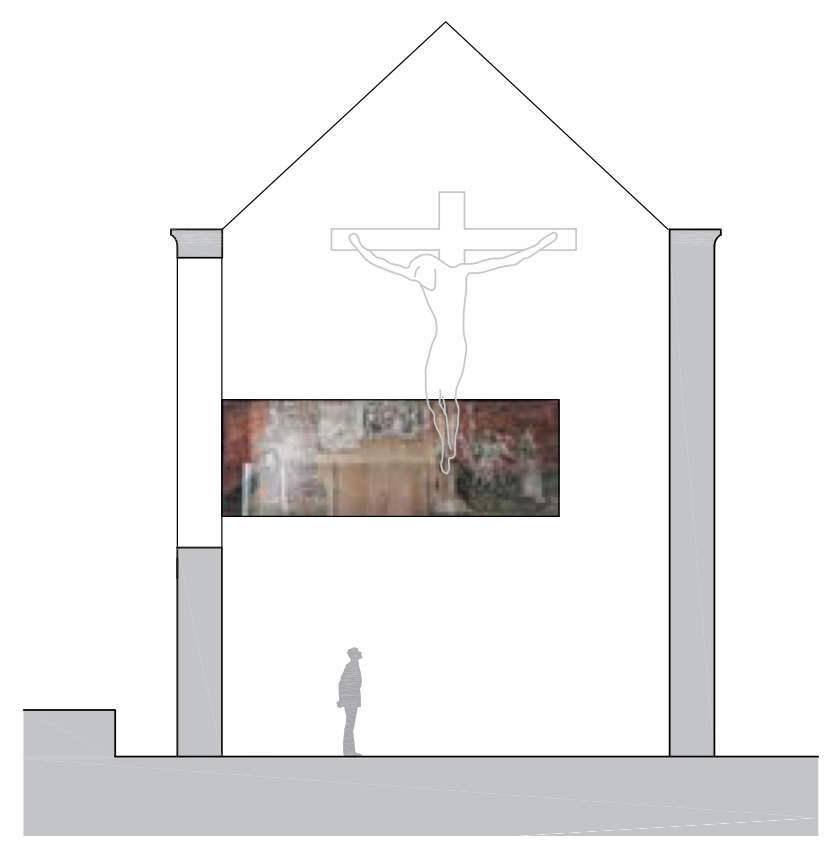

Figure 16: Assumed original transversal section.

medieval painting and certainly this was not the case in the monastic period). This leads to a conclusion that there was actually no first floor and the refectory used to be a double-height room. Other evidence for this conclusion is that the paintings in the refectory were usually located at a height of 2-3 meters from the floor, for reasons of scale (to make it possible to be seen from the ideal angle) and also to re-table the god's importance (in the case of the crucifixion). Today, this is at only 1 meter from the floor where it is located (the first floor) (Figs. 15 and 16). 
The refectory contained two openings on the east side and no windows on the west side, perhaps for the rule of not visual contact with the outside courtyard. The building is accessed from the east side through an opening to the north of the lavatory and the opening in the west would probably link the refectory to the kitchen.

\subsection{Evaluation of possibilities for the reuse of The Charterhouse}

The process of knowledge has been critical to the assessment of the possibilities for the reuse of the Carthusian Priory of Santa Ana and will also be important to tell the story of The Charterhouse to the community of Coventry. The union of all the data collected between historical research and the direct analysis of the building gave us the conditions for planning the reuse of the building, respecting its history and original configuration.

Once the building and the monastic complex was understood, the first step was to determine that the garden - that used to be the cloister - should remain a space of silence since it has been that way in the monastic period. It will be there that the story will be told to visitors of the monastery and the children of the local schools. The gardens outside the walls will be developed for sports and other activities in general because it was the secular space in the monastery. The result of this research and all processed materials will be exhibited in the museum of The Charterhouse with the intuition that the entire Coventry community can learn the history and participate in it from now on.

The future use of the house is still to be confirmed by the trust that owns the house, but the most important decision is that, although it is now known that the building has suffered some important modifications through the years, no work will be done in the attempt to convert the building into its original configuration. All phases are important and it tells the history of The chapterhouse. The only exception will be the reconstruction of one of the cells, where visitors will have the chance to see how the Carthusian monks used to live.

\section{ACKNOWLEDGEMENT}

This article is based on a research run by the author and colleagues while working at the architectural practice PCPT Architects in Birmingham, UK.

\section{REFERENCES}

[1] Frate, M.C., Restauro e Conservazione del Patrimonio Storico, Dario Flaccovio Edditore: Palermo, 2010.

[2] Harrabin, I., The History of the Charterhouse, available at www.charterhousepriory. org.uk (accessed 15 December 2016).

[3] Coppack, G., Christ's Poor Men: The Carthusians in Britain, Tempus, Stroud, UK, 2002.

[4] Monckton, L., Coventry: Medieval Art, Architecture and Archeology in the City and Its Vicinity, Maney Publishing, Leeds, UK, 2010.

[5] Soden, I., Coventry, Excavations at St Anne's Charterhouse 1968-87, Coventry City Council: Coventry, 1990.

[6] Alagna, A., Stratigrafia Per Il Restauro Architettonico: Il Metodo Dell'analisi Stratigrafica Per La Conoscenza E La Conservazione Del Costruito Storico, Aracne: Roma, 2008.

[7] Bortolotto, S., Il Rilievo Stratigrafico, Polimi, Milan, 2004.

[8] Pittaluga, D., \& Boato, A., Building Archaeology: A Non-Destructive Archaeology, available at www.ndt.net/article/wcndt00/papers/idn365/idn365 (accessed 15 December 2016). 